\title{
GRADUATE SCHOOLS IN BRITISH UNIVERSITIES
}

\begin{abstract}
A FEW weeks ago some highly interesting findings wore published* of a Committee set up at Oxford last November "to consider and report on the accommodation, facilities and amenities in the University for graduates of this and other universities". The facts unearthed and the suggestions made show the fast-growing importance of Oxford as a centre of graduate study, particularly in the sciences, and the urgency of eatering for the needs of this graduate population in new ways. Clearly, there is among Oxford dons a body of informed opinion conscious of practicable measures which might be taken to help to deal with the situation. But the report of the Committee has wider implications, too.

In 1939, out of some 5,000 students at Oxford, 520 - or about 10 per cent-were roading for advanced degrees or diplomas; by 1960 this number had grown to 1,758 out of nearly 9,000 , or about 20 per cent. Among the contributory factors to this development are the greatly increased numbers of grants for graduate work, the spread of the practice that scientists should take a research degree as a prelude to an industrial as well as an academic career, and the growing number of graduates from other univer. sities who want to work at Oxford. Not merely have the modern universities much more than twice the student population that they had twenty years ago, but also Oxford and Cambridge have an unrivalled attractiveness both as places of learning and as prestige institutions ("above the social strife"). For many a gradurte they have, consciously or unconsciously, something of the appeal of an Athenæum Club as well as of a university, short though they are of bedrooms and somewhat deficient in comforts. But so far neither hes quite ceught up with itself as a centre of greduate migretion. Traditionally, they have been places at which to get a good undergraduate education, in a college, between the ages of eighteen and twenty-one or so. To-day, however, 92 per cent of Oxford's graduate students are more than twenty-two years of age, and a quarter of them more than twentyfive ; 56 per cent come from other universities and are strangers to Oxford. Many are married, and of these the majority have their wives with them; an appreciable number have their children as well.

What is being done to meet the problems brought about by this state of affairs? The colleges provide some living accommodation, and a certain amount of wise advice is given about lodgings by the University Delegacy. But some of the lodgings are up to fifteen miles from Oxford itself and many stipulate "no children". The costs of good or even satisfactory accommodation are considerable; and outside the eity there is much competition for it from Harwell and the surrounding air bases. The Committee believes that colleges ought to extend to unmarried graduates from other universities the privilege of spending at least their first year in college; and that the University ought to be bold in building flats for married couples and in making grants or loans to colleges to help them to convert houses for the use both of single and of married students.
\end{abstract}

*xford University Gazette, Supp. to Issue No. 3048 (June 16,
But the graduate may find a roof to cover him and still remain a lonely man, with remarkably little to make him feel that he really belongs not merely to a laboratory or a department but also to the University - and this at a time when it may be of great importance to him to feel that he does so belong. He may, it is true, be a member of his college junior common room and go to lunch at Halifax House (424 of the 544 members of which, incidentally, are science graduates), but Halifax House suffers from inadequate buildings and from having nothing like enough money. (The Committee notes that "it is hoped that a new building for Halifax House will be included in the major building programme for 1964 68 ". One would have expected a note of greater urgency than this.) That graduate common rooms should be provided in the colleges is an admirable suggestion (only one college at present has such a room); so is the idea that 'study rooms' should be made available for the use of married graduates living out. It would be a great help, too, if the Delegacy of Lodgings made itself an active centre for relaying information affecting the residence outside college of members of the University. In the wealth of their information services, their skilfully compiled maps and brochures, their welcoming spirit efficiently incorporated into administrative terms, American universities certainly have something to teach both older and newer universities in Britain.

It has to be remembered that many of the men and women going from modern universities to Oxford and Cambridge as graduates will not have been resident before, either at school or in a university. This is a new start for them, an introduction to a wider world than they may have hitherto experienced. There may have been little possibility of finding in their honours school at 'Redbrick' the diverse and yet friendly community which a good college can be : and their time at 'Oxbridge'-in a fresh environment and with widening horizons-may find them ready to be newly and intimately receptive. But the defect of the British social system generally - and one which on occasion has applied to graduates going up to Oxford and Cambridge, whether from 'Redbrick' or' from overseas-is that it leaves so many feeling that they are not quite within the inner circle. This defect is one which the Committee certainly had at the back of its mind. Its suggestions are essentially suggestions about how to make Oxford a more potent educational force in tho lives of the graduates studying within it.

The report, however, has a more wide-spreading significance than for Oxford or 'Oxbridge'. Discernible here is a shift in attitude to the whole problem of the welfare and education of the graduate student and a recognition that if his continued studies are to give him not merely more knowledge and a further degree but also continued-and general - education he must be considered in his own right. The development of graduate schools of character and power is not dependent on the provision of laboratories, libraries, research amenities and supervision alone. This, so far, we have tended not sufficiently to acknowledge : all British universities 
remain unduly orientated to undergraduate needs. Yet the proportion of graduates will rise everywhere during the coming ten, twenty, thirty years; at some universities indeed (at the Imperial College of Science and Technology, London, for example) this policy is already fast being implemented.

In a period when it is the done thing to marry and have children early, especially in the professional classes, and when a parental means test for the graduate student must before long become a thing of the past, is enough thought being given even in the modern universities to the problems involved? The idea of raising the percentage of graduates accommodated in halls of residence by a variety of means, including the addition of specially planned halls for graduates, must be considered. At some universities already a few houses have been admirably adapted to yield numbers of flats for graduate students (though sometimes at the risk of isolating the graduate further from the life of the university); and there are several active graduate students' councils. But the special needs and aptitudes of the graduate for a liberal education as well as for research training have been little regarded.

No doubt, Oxford and Cambridge are likely for some years to come to be magnets to graduates from elsewhere. But other universities, too, are attracting increasing numbers of students from outside themselves (including some from Oxford and Cambridge) and it is surely good that this should be so. Experience of two universities of differing temper and situation is often likely to be more enriching than of one only.

This pioneer report from Oxford is much to be welcomed-for its encouraging facing of local facts; for its wealth of practical ideas; but also for the example it gives other universities to set in motion corresponding investigations and to think thoughts of their own on their provision for the graduate within them.
W. R. NIBLETT

\section{THE INDIAN OCEAN EXPEDITION}

$\mathrm{T}$ HE Special Committee on Oceanic Research, meeting in Copenhagen and Helsinki in July, was set up by the International Council of Scientific Unions in 1957, on the grounds that a new international scientific organization was needed to strengthen and promote research in marine science. It was to initiate joint programmes in consultation with the scientific unions and other organizations. The Committee met for the first time in the Woods Hole Oceanographic Institution in August 1958, and among other measures proposed a joint expedition to the Indian Ocean. It tried to choose the area most likely to attract the attention of scientists, where the work would appeal to world organizations which promote science and human welfare, and where better understanding is likely to prove most immediately useful to the surrounding countries. The Indian Ocean was an obvious choice ${ }^{1}$.

The complete change-round of some of its currents in response to changes in wind direction will give physicists a fairly unique opportunity to study factors that influence water movements. Better knowledge of accompanying biological changes will improve our quantitative understanding of factors that control oceanic productivity. More detailed information about the distribution of fish - especially those that live in mid-ocean-in relation to the boundaries between currents and water layers should advance fisheries science and be readily usable. The Indian Ocean is an ocean with exceptional and prominent features. The exchange of energy between sea and air has much to do with the powerful monsoon winds, and any improvement in long-term forecasting of their onset and intensity will be very useful. We know there are large fish populations in mid-ocean, and records of tremendous mass mortalities occurring from time to time show that they live in critical marginal conditions. In geophysics, as in other aspects, the Indian Ocean offers attractive sites for research.

The justice of trying to boost science by pledging the enticipated success of a new scheme has rightly been questioned, and there is no doubt of the sincerity and good intentions of the editor of the privately circulated "Indian Ocean Bubble", which has voiced very reasonable opposition. He does not quite say that skilled young scientists who form the real backbone of our research laboratories will be swindled by the promoters, but he criticizes the prosspectus which probably has promised too much, and sounds a clear warning about the ill effects of hindering new approaches and critical experiments by too much regimented and routine work. He makes chilling reference to recent books, "The Tragic History of the Sea", by C. R. Boxer - three accounts of disastrous early Indian Ocean expeditions and "The South Sea Bubble", by John Carswell-a general popular account of the venture that he frightens us with.

The effort devoted to marine science is, however, in no way commensurate with the magnitude, variety and difficulty of the problems it has to solve, and after a hundred years work, much of it devoted to fishery problems, we have little idea about the distribution of current with depth in any ocean. We can quote another editor who hailed the departure of one of our greatest expeditions to the Southern Seas with the words, "We may wait, it is true, and consign to centuries to come, the toils, the glories and the hopes of science, or we may rely on an easy effort distributed over length of years for the accomplishment of much that vigorous exertion might now effect". He continues, "There are secrets of Nature we would fain see revealed while we yet live in the flesh-resources hidden in her fertile bosom for the woll-boing of man upon Earth we would fain see opened up for the use of the generation to which we belong. But if we would be enlightened by the one or benefited by the other, we must lay on power both moral and physical without grudging and without stint". He makes a more encouraging reference to the poet who wrote:

$$
\begin{aligned}
& \text { "Nimm die Zögernde zum Rath } \\
& \text { Nicht zum Werkzeug deiner That" }
\end{aligned}
$$

These admonitions appeared in the Quarterly Review 120 years ago, and they are as timely and wellintentioned as the new cautions. 